\title{
Effects of Seed Hydropriming on Germination and Seedling Vigor during Emergence of Rice under Different Soil Moisture Conditions
}

\author{
Ken-Ichi Matsushima ${ }^{1}$, Jun-Ichi Sakagami ${ }^{12^{* *}}$ \\ ${ }^{1}$ Japan International Research Center for Agricultural Science, Tsukuba, Japan; ${ }^{2}$ Kagoshima University, Kagoshima, Japan. \\ Email: "sakajun@affrc.go.jp
}

Received May 20 ${ }^{\text {th }}, 2013$; revised June 21 $1^{\text {st }}, 2013$; accepted July $15^{\text {th }}, 2013$

Copyright (C) 2013 Ken-Ichi Matsushima, Jun-Ichi Sakagami. This is an open access article distributed under the Creative Commons Attribution License, which permits unrestricted use, distribution, and reproduction in any medium, provided the original work is properly cited.

\begin{abstract}
Seed priming is a physiological seed enhancement method. Hydro- or osmotic priming can advance germination under adequate moisture conditions. During direct seeding on well-drained paddy and upland fields, rice seeds occasionally encounter low soil moisture conditions. Under these conditions, rice seeds need to undergo rapid germination and secure emergence through improved water absorption capacity and seed bioactive. This study aims to clarify the effects of seed hydropriming on germination and seedling vigor in rice under different soil moisture conditions. The study employed three hydration conditions such as priming, soaking, and control. The seeds to be primed and soaked were submerged in tap water at $30^{\circ} \mathrm{C}$ for $12 \mathrm{~h}$. For priming, the seeds were subsequently dried to attain their initial seed weight, but the seeds for soaking were not dried before sowing, and the control seeds were untreated. In addition, different soil moisture conditions, such as $3 \%, 6 \%, 8 \%, 11 \%, 15 \%$, and $20 \%$, were set. Therefore, emergence time shortened with seed priming at $3 \%-11 \%$ soil moisture contents. In particular, at $8 \%$ soil moisture content, priming and soaking decreased emergence time by $26.8 \mathrm{~h}$ and $21.7 \mathrm{~h}$, respectively compared with that of the control. At $8 \%-15 \%$ soil moisture contents, shoot elongation rate obtained with the priming seeds increased $>1.2$ times compared with that obtained with the control and soaking seeds. At $>8 \%$ soil moisture content, shoot dry weight obtained with the priming seeds increased $>1.3$ times compared with that obtained with the soaking seeds. Furthermore, at declining soil moisture conditions, the increase in root dry weight is promoted by seed priming compared with that in the control seeds. These results suggest that increased root growth affects plant water absorption under low soil moisture conditions due to priming. This study demonstrates that seed priming facilitates rapid emergence and seedling vigor, unless extremely dry or flooded soil moisture conditions are present at seeding.
\end{abstract}

Keywords: Rice; Seed Emergence; Seedling Vigor; Shoot Elongation; Soil Moisture

\section{Introduction}

Seed priming, which is also called seed hardening, is a physiological seed enhancement method [1]. Heydecker (1973) defined seed priming as a presowing treatment in which seeds are soaked in an osmotic solution that allows them to imbibe water and go through the first stages of germination, but does not permit radicle protrusion through the seed coat [2]. Subsequently, the seeds can be dried to attain their original moisture content and stored or planted using conventional techniques. Seed priming is a hydration treatment that allows controlled imbibition

${ }^{*}$ Corresponding author. and induction of pregerminative metabolism $[3,4]$. Several different priming methods have been commercially used, such as water or osmotic treatment using aqueous solutions, e.g., $\mathrm{KCl}$ and $\mathrm{CaCl}_{2}$, and priming and solid matrix priming, which appear to have the greatest effect on seed and seedling vigor in some crops $[5,6]$.

Seed priming with water has been studied in some vegetables, including carrot, onion, and tomato [7-10], wheat [11], and some weeds [12]. Seed priming is a very efficient technique to increase the speed of germination without compromising on germination rates and in some plant species, the seeds obtained with priming emerge from the soil faster and often more uniformly than non- 
primed seeds. In addition, in environmental soil conditions, water- or osmotic priming as well as low and high temperatures with onion [13], canola [14], and asparagus [15]; shortage or excess water with okra [8] and salinity with wheat $[16,17]$ provide rapid and uniform germination and emergence $[5,18]$.

Under adequate moisture conditions, seed priming in rice improves the speed and germination rate of the seeds $[19,20]$ and the speed of emergence and growth of the shoot [21-25]. In addition, Farooq et al. (2004) and Basra et al. (2005) demonstrated that both the speed of germination and emergence improved in rice under adequate moisture conditions [26,27]. Furthermore, these reports demonstrate that seed priming is effective for improving the ability of seed germination and seedling vigor. Emergence is defined as the time when a coleoptile projects from the soil surface. Therefore, to demonstrate that the speed of emergence is faster because of seed priming, the participation of seed priming in the growth process after germination must be investigated. In contrast, seeded rice may occasionally encounter a low soil moisture condition when directly seeded on a well-drained paddy or upland field. Dry soil at seeding promotes delay and non-uniform emergence, and it may result in a decline of yield and luxuriant weed growth. Low and high soil moisture conditions inhibit water absorption and respiration of seeds and seedlings, respectively. Therefore, it is important to identify the range of soil moisture condition that affects seed priming. Andoh and Kobata (2000) reported that some rice varieties show improved emergence speed and seedling growth following seed priming under low soil moisture conditions [28]. Lee et al. (1998) demonstrated that the effects of seed priming on radicle length are greater under optimum soil moisture conditions than that under the lack of or excess soil moisture conditions [29]. These reports are useful to demonstrate that seed priming improves seedling vigor under diverse soil moisture conditions. However, these studies did not consider whether flood and dry stress at germination and during early growth can be avoided with seed priming. Furthermore, these reports did not consider the effects of soil moisture content and seed priming on the growth ratio of radicle and seminal roots during emergence. It is important to resolve these issues because unlike vegetables, in rice cultivation, it is necessary to ensure establishment of good seedlings under an extensive management. This study aims to clarify the effect of seed priming on emergence and seedling vigor of rice under different soil moisture conditions. We soaked seeds immediately before sowing to avoid water absorption stress at germination. Direct sowing was not practical because of the increased risk of drying.

\section{Materials and Methods}

Seeds of the rice cultivar "Koshihikari" harvested in 2008 were used in this study. Moisture content and grain weight of the seeds were $11.5 \%$ and $2.59 \mathrm{mg}$, respectively. The study employed three hydration conditions: 1) Priming seeds were submerged in tap water at $30^{\circ} \mathrm{C}$ for $12 \mathrm{~h}$, dried back to attain initial seed weight before submerging in water at $25^{\circ} \mathrm{C} ; 2$ ) Soaking seeds were submerged in tap water at $30^{\circ} \mathrm{C}$ for $12 \mathrm{~h}$ just before sowing; 3) Control seeds were not submerged or dried. Soil moisture conditions were set up as $3 \%, 6 \%, 8 \%, 11 \%, 15 \%$, and $20 \%$ soil moisture contents, which is the ratio of water to soil weight. Soil moisture content was determined with three replications from soil weight before and after drying at $105^{\circ} \mathrm{C}$ for $24 \mathrm{~h}$ [30]. Sand gathered from the bottom of a river at Sakura, Ibaraki, was used. Field capacity of the soil was assessed using a method described by Kawaguchi (1974) [31]. The field capacity of the soil was $22.2 \%$ at soil moisture content. For $3 \%, 6 \%, 8 \%$, $11 \%, 15 \%$, and $20 \%$ soil moisture contents, the field capacity of the soil was $10.8 \%, 24.0 \%, 30.5 \%, 43.3 \%$, $61.8 \%$, and $87.6 \%$, respectively.

Germination was investigated using 6-cm Petri dishes. Soil of 1-cm depth was filled in the Petri dishes to regulate moisture. Five seeds were sown in each dish and then covered with soil of $0.5-\mathrm{cm}$ depth. The number of germinated seeds was measured every $6 \mathrm{~h}$ during the first $12 \mathrm{~h}$ and every $12 \mathrm{~h}$ up to $60 \mathrm{~h}$ after sowing. The three dishes each hydration conditions were chosen at these measured timing. The time to achieve $50 \%$ germination was calculated using the following formula.

$$
\begin{aligned}
& \text { Germination time } \\
& =\mathrm{ti}+(\mathrm{N} / 2-\mathrm{ni}) \times(\mathrm{tj}-\mathrm{ti}) /(\mathrm{nj}-\mathrm{ni})
\end{aligned}
$$

where $\mathrm{N}$ is the final number of seeds that germinated and $\mathrm{ni}$ and $\mathrm{nj}$ are the cumulative number of seeds germinated by adjacent counts at time ti and $\mathrm{tj}$, respectively, when $\mathrm{ni}$ $<\mathrm{N} / 2<\mathrm{nj}$.

Emergence time and growth of shoots and roots were investigated in three replications using $100-\mathrm{ml}$ beakers (5.0-cm diameter, $7.0-\mathrm{cm}$ height). The beakers were filled with soil of $5-\mathrm{cm}$ depth to regulate moisture. Eight seeds were sown in each beaker and covered with soil of $0.5-\mathrm{cm}$ depth. Emergence was measured every $12 \mathrm{~h}$ after sowing. The seedlings were taken out after sowing for 84 h. Shoot length and dry weight of the shoot and root were measured and the ratio of shoot dry weight and root dry weight (T/R ratio) was calculated. The time to achieve $50 \%$ emergence was calculated using the formula previously mentioned.

Statistical analysis was conducted using an analysis of variance followed by Tukey's test. A $P$-value of $<0.05$ was considered significant. 


\section{Results}

\subsection{Germination, Emergence, and Dry Matter Production under Different Soil Moisture Conditions}

Germination time of the control was 40.0, 40.3, 43.0, $48.5,50.2$, and $50.0 \mathrm{~h}$ at $3 \%, 6 \%, 8 \%, 11 \%, 15 \%$, and $20 \%$ soil moisture, respectively (Figure 1). Germination time of rice was shortened $3.3,8.5,8.5,13.5,7.7$, and 3.7 $\mathrm{h}$ by priming and $13.7,10.0,16.2,19.8,12.7$, and $11.0 \mathrm{~h}$ by soaking compared with that of the control at $3 \%, 6 \%$, $8 \%, 11 \%, 15 \%$ and $20 \%$ soil moisture contents, respectively (Figure 1). Germination time of the priming seeds was significantly shorter than that of the control seeds at $6 \%, 11 \%$, and $15 \%$ soil moisture contents and of the soaking seeds was shorter than that of the control seeds at all soil moisture contents, except at $20 \%$. Germination time of seeds obtained with priming seeds increased by $1.5,10.4,7.7,6.3,5.0$, and $7.3 \mathrm{~h}$ compared with that of soaking seeds at $3 \%, 6 \%, 8 \%, 11 \%, 15 \%$, and $20 \%$ soil moisture contents, respectively, but no significant difference was found between priming and soaking seeds at all soil moisture levels, except at 3\%.

Emergence time of the control was $80.3,86.3,82.7$, $84.0,73.0$, and $89.8 \mathrm{~h}$ at $3 \%, 6 \%, 8 \%, 11 \%, 15 \%$, and $20 \%$ soil moisture contents, respectively (Figure 1). Emergence time of priming and soaking seeds was shortened 8.3, 22.2, 26.8, and 23.8 $\mathrm{h}$ and 8.3, 17.5, 21.7, and $19.1 \mathrm{~h}$, respectively, compared with that of the control at $3 \%, 6 \%, 8 \%$, and $11 \%$ soil moisture contents, respectively. Emergence time tended to be shorter with the priming seeds than that with the soaking seeds among those exposed to $6 \%-11 \%$ soil moisture, but no significant difference was observed. Ratios of priming seeds to control seeds during the period from germination to emergence were $0.88,0.70,0.55$, and 0.72 at $3 \%, 6 \%$, $8 \%$, and $11 \%$ soil moisture contents, respectively. The period from germination to emergence was significantly shorter with the priming seeds than that with the control seeds at $6 \%, 8 \%$, and $11 \%$ soil moisture contents. The ratios of priming seeds to soaking seeds from germination to emergence were $0.77,0.84,0.63$, and 0.71 at $3 \%$, $6 \%, 8 \%$, and $11 \%$ soil moisture contents, respectively. Significant differences were found between priming and
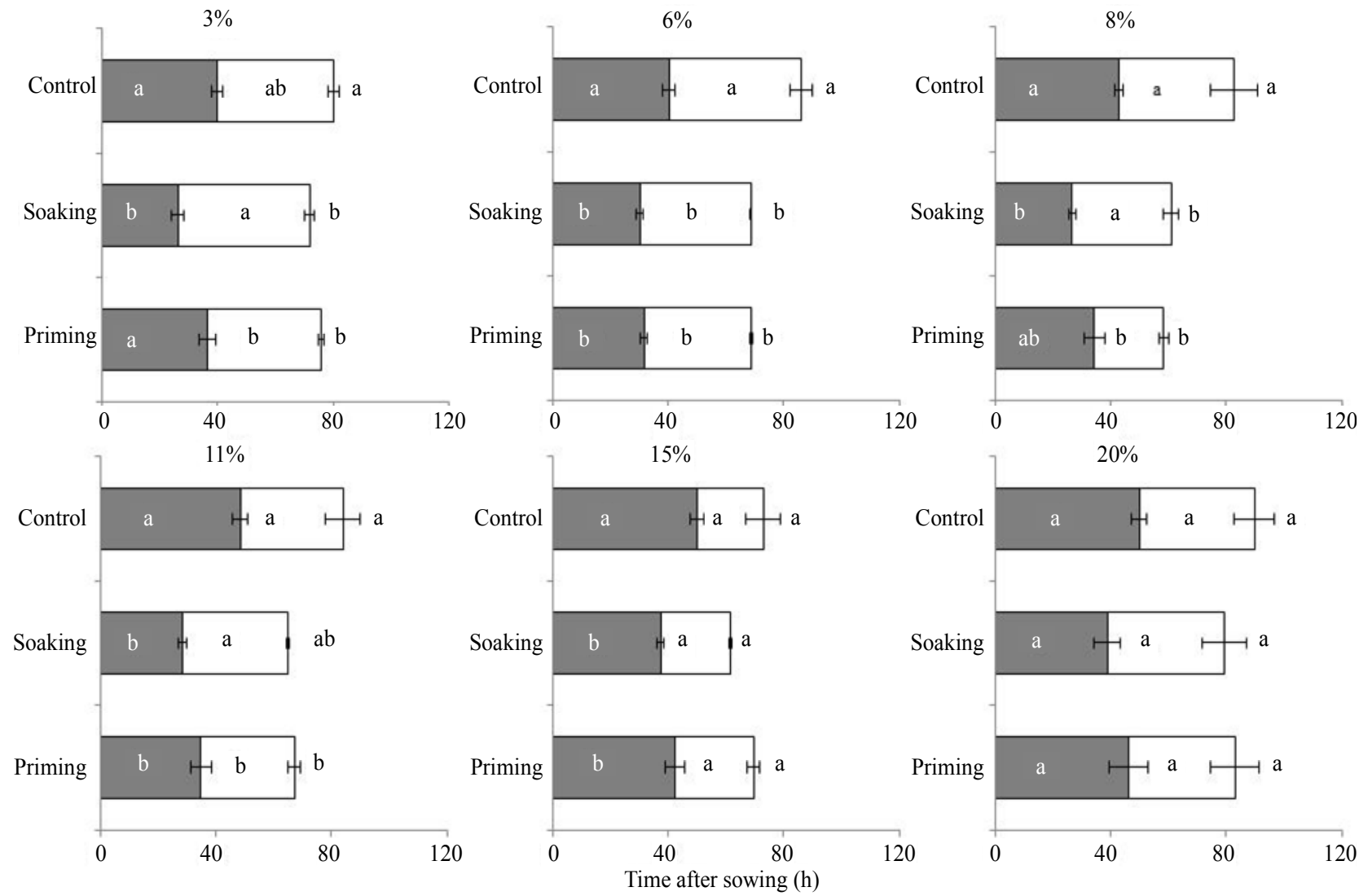

Figure 1. Germination and emergence time at each soil moisture condition. Bar is standard error for germination and emergence time. The mean values, obtain from Tukey's test, sharing the same letters are not differ significantly $(P<0.05)$. Percentages in each figure indicate soil moisture content. Shaded and non-shaded bars represent germination time and emergence time after germination. 
soaking seeds from germination to emergence at all soil moisture levels, except at $6 \%$. The ratios of soaking seeds to control seeds from germination to emergence were $1.13,0.84,0.86$, and 1.02 at $3 \%, 6 \%, 8 \%$, and $11 \%$ soil moisture contents, respectively. No significant differences were found between the soaking and control seeds from germination to emergence at all soil moisture contents, except at $6 \%$. At $15 \%$ and $20 \%$ soil moisture contents, no significant differences were observed among the priming, soaking, and control seeds.

Shoot length of the seeds obtained with priming increased significantly compared with that in the control seeds at all soil moisture contents, except at $20 \%, 84 \mathrm{~h}$ after sowing (Table 1). The shoot length obtained with priming seeds was 1.5 and 1.8 times that obtained with the control seeds at $3 \%$ and $6 \%$ soil moisture content, respectively, and 1.6 times that obtained with control seeds at $8 \%, 11 \%$, and $15 \%$ soil moisture content. Shoot length tended to be longer with priming seeds than that with the soaking seeds at $8 \%, 11 \%$, and $15 \%$ soil moisture contents, but no significant differences were observed between the soaking and priming seeds at any soil moisture contents, except at $15 \%$. At $20 \%$ soil moisture content, shoot length tended to be longer with priming seeds than that with the control seeds, but the difference was not significant.

Shoot elongation rate from germination to $84 \mathrm{~h}$ after sowing was significantly higher with priming seeds than with control seeds at all soil moisture contents, except at $20 \%$, and with the priming seeds than that with the soaking seeds at $8 \%, 11 \%$, and $15 \%$ soil moisture contents (Table 1). At $20 \%$ soil moisture content, no significant difference was observed in the shoot elongation rate between the hydration plots. Shoot elongation rate with the priming seeds was $>1.2$ times ( $11 \%$ soil moisture content) that with control seeds at all soil moisture contents, except at $20 \%$. However, the shoot elongation rate with the soaking seeds was similar to that with the control seeds at $8 \%, 11 \%, 15 \%$, and $20 \%$ soil moisture contents and with the priming seeds at $3 \%$ and $6 \%$ soil moisture contents.

Shoot dry weight with the priming seeds tended to increase compared with that with the control seeds at all soil moisture contents, but a significant difference was found only at $11 \%$ and $15 \%$ soil moisture contents. Root dry weight tended to be larger with the soaking and priming seeds than that with the control seeds at all soil moisture contents.

Table 1. Effect of treatment on shoot length, and shoot and root dry matter weight.

\begin{tabular}{|c|c|c|c|c|c|}
\hline Soil moisture content & Treatment & Shoot length (mm) & $\begin{array}{l}\text { Shoot elongation rate } \\
\left(\mathrm{mm} \cdot \mathrm{h}^{-1}\right)\end{array}$ & $\begin{array}{c}\text { Shoot dry weight } \\
\left(\mathrm{mg} \cdot \text { plant }^{-1}\right)\end{array}$ & $\begin{array}{c}\text { Root dry weight } \\
\left(\mathrm{mg} \cdot \text { plant }^{-1}\right)\end{array}$ \\
\hline \multirow[t]{2}{*}{$3 \%$} & Control & $9.0 \pm 1.01 \mathrm{~b}$ & $0.21 \pm 0.01 b$ & $0.63 \pm 0.13 b$ & $0.95 \pm 0.28 \mathrm{a}$ \\
\hline & Priming & $13.1 \pm 0.37 \mathrm{a}$ & $0.28 \pm 0.02 \mathrm{a}$ & $0.88 \pm 0.03 \mathrm{ab}$ & $1.28 \pm 0.03 \mathrm{a}$ \\
\hline \multirow[t]{3}{*}{$6 \%$} & Control & $8.2 \pm 0.83 b$ & $0.19 \pm 0.01 b$ & $0.70 \pm 0.08 \mathrm{a}$ & $0.76 \pm 0.22 \mathrm{a}$ \\
\hline & Soaking & $16.5 \pm 2.12 \mathrm{a}$ & $0.31 \pm 0.01 \mathrm{a}$ & $1.45 \pm 0.21 \mathrm{a}$ & $1.54 \pm 0.23 \mathrm{a}$ \\
\hline & Priming & $14.9 \pm 0.67 \mathrm{a}$ & $0.29 \pm 0.03 \mathrm{a}$ & $1.09 \pm 0.06 \mathrm{a}$ & $1.55 \pm 0.41 \mathrm{a}$ \\
\hline \multirow[t]{3}{*}{$8 \%$} & Control & $11.1 \pm 1.55 \mathrm{~b}$ & $0.27 \pm 0.02 b$ & $0.83 \pm 0.11 \mathrm{a}$ & $0.74 \pm 0.06 \mathrm{ab}$ \\
\hline & Soaking & $14.9 \pm 0.55 \mathrm{ab}$ & $0.26 \pm 0.03 b$ & $1.09 \pm 0.07 \mathrm{a}$ & $0.69 \pm 0.07 b$ \\
\hline & Priming & $17.8 \pm 0.60 \mathrm{a}$ & $0.36 \pm 0.01 \mathrm{a}$ & $1.16 \pm 0.08 \mathrm{a}$ & $1.02 \pm 0.10 \mathrm{a}$ \\
\hline \multirow[t]{3}{*}{$11 \%$} & Control & $11.8 \pm 0.52 b$ & $0.33 \pm 0.02 b$ & $0.76 \pm 0.08 \mathrm{~b}$ & $0.49 \pm 0.01 b$ \\
\hline & Soaking & $17.4 \pm 1.18 \mathrm{a}$ & $0.31 \pm 0.01 b$ & $1.18 \pm 0.10 b$ & $0.67 \pm 0.11 \mathrm{ab}$ \\
\hline & Priming & $19.1 \pm 0.93 \mathrm{a}$ & $0.39 \pm 0.01 \mathrm{a}$ & $1.46 \pm 0.07 \mathrm{a}$ & $1.10 \pm 0.10 \mathrm{a}$ \\
\hline \multirow[t]{3}{*}{$15 \%$} & Control & $11.8 \pm 0.53 b$ & $0.35 \pm 0.03 b$ & $0.74 \pm 0.01 b$ & $0.50 \pm 0.10 \mathrm{a}$ \\
\hline & Soaking & $14.2 \pm 0.41 b$ & $0.31 \pm 0.01 b$ & $0.88 \pm 0.07 b$ & $0.68 \pm 0.15 a$ \\
\hline & Priming & $18.8 \pm 1.28 \mathrm{a}$ & $0.45 \pm 0.02 \mathrm{a}$ & $1.13 \pm 0.06 \mathrm{a}$ & $0.71 \pm 0.11 \mathrm{a}$ \\
\hline \multirow[t]{3}{*}{$20 \%$} & Control & $4.7 \pm 0.74 \mathrm{a}$ & $0.14 \pm 0.02 \mathrm{a}$ & $0.23 \pm 0.07 b$ & $0.23 \pm 0.04 \mathrm{a}$ \\
\hline & Soaking & $6.9 \pm 0.67 \mathrm{a}$ & $0.15 \pm 0.02 \mathrm{a}$ & $0.25 \pm 0.02 \mathrm{ab}$ & $0.20 \pm 0.01 \mathrm{a}$ \\
\hline & Priming & $7.2 \pm 0.82 \mathrm{a}$ & $0.19 \pm 0.01 \mathrm{a}$ & $0.41 \pm 0.05 \mathrm{a}$ & $0.22 \pm 0.04 \mathrm{a}$ \\
\hline
\end{tabular}

Data are represented as mean \pm standard error $(n=3)$; Mean values sharing the same letters do not differ significantly $(P<0.05$; Tukey's test $)$. 


\subsection{Relationship between Soil Moisture and Growth Parameters}

A significant positive correlation $(P<0.05)$ was observed between soil moisture content and germination time in the control, soaking, and priming seeds (Figure 2(a)). Linear regression between these parameters in the control, soaking, and priming seeds revealed $\mathrm{r}=0.915$, 0.881 , and 0.837 , respectively. A significant single curve correlation $(P<0.01)$ was observed between soil mois- ture content and emergence time in the soaking and priming seeds, but not in the control seeds $(\mathrm{r}=0.395)$ (Figure 2(b)). Single curve regression between these parameters in the soaking and priming seeds revealed $\mathrm{y}=$ $0.195 \mathrm{x}^{2}-4.185 \mathrm{x}+84.136(\mathrm{r}=0.918)$ and $\mathrm{y}=0.237 \mathrm{x}^{2}-$ $4.630 \mathrm{x}+82.442(\mathrm{r}=0.957)$, respectively. According to these curves, the soil moisture contents with the soaking and priming seeds for the shortest emergence were $10.7 \%$ and $9.8 \%$, respectively.
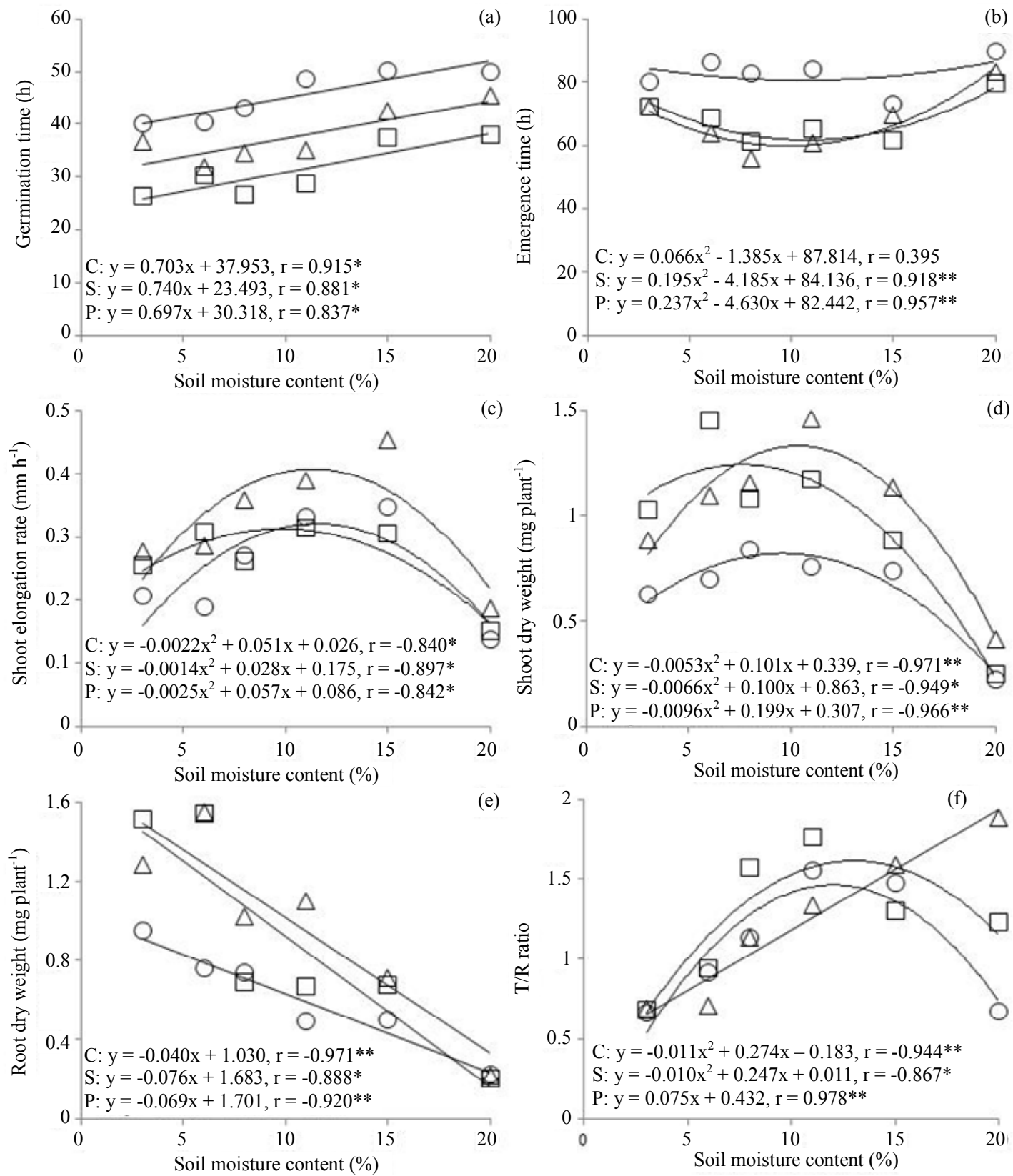

Figure 2. Relationship between soil moisture contents and Germination time (a), Emergence time (b), Shoot elongation rate (c), Shoot dry weight (d), Root dry weight (e), T/R ratio (f). Circles, triangles and squares symbols and $\mathrm{C}, \mathrm{P}$ and $\mathrm{S}$ represent the conditions Control, Priming and Soaking, respectively. $* P<0.05, * * P<0.01$. 
A significant single curve correlation was found between soil moisture content and shoot elongation rate $(P$ $<0.05$, Figure 2(c)) with the control, soaking, and priming seeds. Single curve regression between these parameters in the control, soaking, and priming seeds revealed $\mathrm{y}=-0.0022 \mathrm{x}^{2}+0.051 \mathrm{x}+0.026(\mathrm{r}=-0.840), \mathrm{y}=$ $-0.0014 \mathrm{x}^{2}+0.028 \mathrm{x}+0.175(\mathrm{r}=-0.897)$, and $\mathrm{y}=$ $-0.0025 \mathrm{x}^{2}+0.057 \mathrm{x}+0.086(\mathrm{r}=-0.842)$, respectively (Figure 2(c)). According to these curves, the soil moisture contents for the most effective shoot elongation rate were $11.6 \%, 10.0 \%$, and $9.8 \%$ with the control, soaking, and priming seeds, respectively. Shoot elongation rate was higher with the priming seeds than that with the soaking and control seeds at all soil moisture contents. A significant single curve correlation was found between soil moisture content and shoot dry weight $(P<0.01$, Figure 2(d)) in the control, soaking, and priming seeds. Single curve regression between these parameters in the control, soaking, and priming seeds revealed $\mathrm{y}=$ $-0.0053 \mathrm{x}^{2}+0.101 \mathrm{x}+0.339(\mathrm{r}=-0.971), \mathrm{y}=-0.0066 \mathrm{x}^{2}$ $+0.100 \mathrm{x}+0.863(\mathrm{r}=-0.949)$, and $\mathrm{y}=-0.0096 \mathrm{x}^{2}+$ $0.199 x+0.307(r=-0.966)$, respectively (Figure 2(d)). According to these curves, the soil moisture contents for most effective shoot elongation were $9.5 \%, 7.6 \%$, and $10.4 \%$ in the control, soaking, and priming seeds, respectively. Shoot dry weight of the priming seeds decreased compared with that of the soaking seeds at $<7.2 \%$ based on these curves. In addition, shoot dry weight was higher in the priming and soaking seeds than that in the control.

A significant negative correlation $(P<0.05)$ was observed between soil moisture contents and root dry weight in each of the seeds (Figure 2(e)). Linear regression between these parameters in the control, soaking, and priming seeds revealed $r=-0.971,-0.888$, and -0.920 , respectively.

A significant single curve correlation was found between soil moisture content and the T/R ratio $(P<0.05$, Figure 2(f)) in the control and soaking seeds. Single curve regression between these parameters in the control and soaking seeds revealed $\mathrm{y}=-0.011 \mathrm{x}^{2}+0.274 \mathrm{x}$ $-0.183(\mathrm{r}=-0.867)$ and $\mathrm{y}=-0.010 \mathrm{x}^{2}+0.247 \mathrm{x}+0.011$ $(\mathrm{r}=-0.943)$, respectively. A significant positive correlation $(P<0.01)$ was observed between the soil moisture content and $\mathrm{T} / \mathrm{R}$ ratio in the priming seeds. Linear regression between these parameters in the priming seeds revealed $y=0.075 x+0.432(r=0.978)$.

\subsection{Relationship between Emergence and Shoot Elongation}

A significant positive correlation was found between shoot dry weight and shoot length $(\mathrm{r}=0.943, P<0.001)$, and root dry weight $(\mathrm{r}=0.718, P<0.001)$ at $84 \mathrm{~h}$ after sowing (Figures 3(a) and (b)). Linear regression between shoot dry weight and shoot length revealed $\mathrm{y}=$ $11.419 \mathrm{x}-2.824$ and root dry weight $\mathrm{y}=0.879 \mathrm{x}+0.048$, respectively. Shoot elongation was accompanied by dry matter production. A significant negative correlation was observed between germination time and growth parameters such as shoot dry weight $(\mathrm{r}=-0.638, P<0.01)$ and root dry weight $(\mathrm{r}=-0.654, P<0.01)$, but not between germination time and shoot elongation rate $(\mathrm{r}=$ -0.123 ) (Table 2). A significant negative correlation was observed between emergence time and growth parameters such as shoot elongation rate $(\mathrm{r}=-0.640, P<0.01)$, shoot dry weight $(\mathrm{r}=-0.772, P<0.001)$, and root dry weight $(\mathrm{r}=-0.490, P<0.05)$. The shorter emergence time was increased dry matter production.

\section{Discussion}

\subsection{Relationship between Shortened Emergence and Shoot Growth Due to Seed Priming}

The shortened emergence time and increased shoot growth (Figures 1 and 2(c), Table 1) observed in this study were consistent with those of previous studies
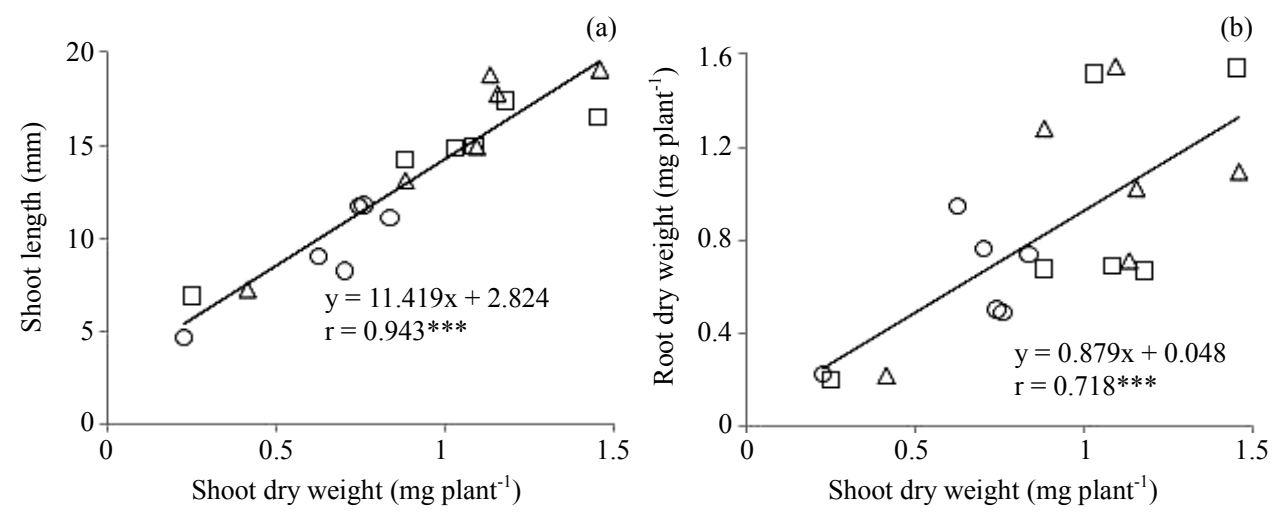

Figure 3. Relationship between Shoot dry weight and Shoot length (a), Root dry weight (b). Circles, triangles and squares represent Control, Priming, and Soaking, respectively. $* * * P<0.001$. 
Table 2. Correlation coefficient between time of germination and growth parameters.

\begin{tabular}{cccc}
\hline & $\begin{array}{c}\text { Shoot elongation } \\
\text { rate }\end{array}$ & $\begin{array}{c}\text { Shoot dry } \\
\text { weight }\end{array}$ & $\begin{array}{c}\text { Root dry } \\
\text { weight }\end{array}$ \\
\hline Germination time & -0.123 & $-0.638^{* *}$ & $-0.654^{* *}$ \\
Emergence time & $-0.640^{* *}$ & $-0.772^{* *}$ & $-0.490^{*}$ \\
\hline
\end{tabular}

${ }^{*} P<0.05,{ }^{* *} P<0.01$.

[22-28]. However, in this study, it is noteworthy that the period from germination to emergence was shorter for priming seeds than that for soaking seeds at $<11 \%$ soil moisture content (Figure 1), indicating that this period does not decrease due to seed soaking alone. Shoot elongation rate was similar between seeds obtained by soaking and priming at $3 \%$ and $6 \%$ soil moisture contents, although germination time was longer in those obtained with priming than with soaking (Figure 1 and Table 1). At $8 \%$ and $11 \%$ soil moisture contents, shoot length and shoot elongation rate were higher with priming seeds than with soaking seeds (Table 1). To increase shoot elongation rate, an increase in the number and/or size of the cell is necessary. Although there is no known relationship between cell division and seed priming in rice, but replicative DNA synthesis in radicle meristem nuclei often occurs in tomato during seed priming, although this is not essential to advance germination [3]. In addition, in this study, increase in shoot length and shoot dry weight were observed (Figure 3(a)), suggesting that the rapid supply of nutrients required for cell growth, which is obtained with seed priming is involved in the increase of shoot elongation rate. The physiologically active state of pre-germinated seeds is improved by seed priming. In rice seeds, the metabolic process related to $\alpha$-amylase activity is activated by water absorption with seed priming and the metabolic potential is preserved in the seed during the dry period after seed priming [32]. A significant positive correlation is observed between $\alpha$-amylase activity and sugar content during seed priming [22,23,33]. These reports suggest that with seed priming before sowing, carbohydrate in the seed is ready to be used for cell elongation. Furthermore, a significant positive correlation between seedling dry weight at 15 days after emergence and sugar content of rice seeds during seed priming is observed [22]. Therefore, growth of rice shoots increases with seed priming because of the increase in soluble carbohydrate supply owing to the increase in activated $\alpha$-amylase. These metabolic changes in the seed are expressed during the drying process after water absorption with seed priming, which may increase the amount or speed of metabolism itself. In soaking seeds, the beginning of water absorption occurred $12 \mathrm{~h}$ earlier compared with that in the control seeds. Therefore, the period from germination to emergence may not shorten because the increased metabolic activity is dependent on the advancement of water absorption.

At $15 \%$ and $20 \%$ soil moisture contents, emergence time was similar between the seeds obtained with hydration treatments and the control seeds (Figure 1). At these soil moisture contents particularly at $20 \%$, standing water was observed and anaerobic conditions probably developed. Under anaerobic condition, rice seeds germinate by coleoptile elongation [34,35]. However, in some rice genotypes, germination time is longer under anaerobic than aerobic conditions [36-38]. Germination time tended to decrease and shoot elongation rate and shoot dry weight increased with seed priming (Figures 1 and 2). In contrast, germination time was longer under aerobic than anaerobic conditions (Figure 1). As previously stated, seeds obtained with priming undergo metabolic changes. However, $\alpha$-amylase activity and the rate of decrease in starch content of seeds are lower in anaerobic seedlings than those in aerobic seedlings [39], although some tolerant genotypes maintain a high $\alpha$-amylase activity under low oxygen stress [40]. It is difficult to determine whether the rice variety "Koshihikari" used in the present study was an anaerobic tolerant genotype because other reports $[39,40]$ did not include "Koshihikari". Therefore, aerobic conditions are required to facilitate the supply of nutrients from the seed for the growth of the shoot. However, in this study, the seeds were exposed to anaerobic conditions at $15 \%$ and $20 \%$ soil moisture contents. Therefore, this study considered that the metabolic changes were not entirely exhibited at $15 \%$ and $20 \%$ soil moisture contents. These considerations may be the reason for the absence of difference in emergence time between the control seeds and the seeds obtained with priming. However, seedlings (coleoptile) are exposed to aerobic conditions after emergence, which probably encourages the smooth progress of $\alpha$-amylase activity that may be enhanced with seed priming. Increased shoot length and dry weight with seed priming that was observed in this study at $84 \mathrm{~h}$ after sowing (Table 1) may support this consideration.

\subsection{Relationship between Soil Moisture and Seedling Vigor Following Seed Priming}

Under low soil moisture conditions, Andoh and Kobata (2000) reported that seminal root length and shoot length of some rice cultivars are longer with priming seeds than those with control seeds [28]. Lee et al. (1998) demonstrated that the effects of seed priming on plumule and radicle length are greater under optimum soil moisture conditions than those under a lack of or excess soil moisture [29]. Our results that shoot length and dry weight 
were greater with the priming seeds than with the control seeds and the negative single curve correlation between shoot dry weight and soil moisture content (Table 1 and Figure 2(d)) agree with previous reports. In contrast, regardless of soil moisture condition, our result that shoot growth increased with priming seeds compared with that obtained with the control seeds (Table 1) demonstrated that seedling vigor with priming seeds is adaptable to a wide range of soil moisture conditions.

The dry weights of shoots and roots were expressed by a single curve and a negative linear correlation, respectively (Figures 2(d) and (e)). This result shows that the reaction to soil moisture was different for shoot and root growth. Sato and Maruyama $(2002,2005)$ reported that root dry weight decreases with an increase in soil moisture content and is lower in flooded than in drained soil $[41,42]$. However, the gradients of the correlations were larger in the soaking and priming seeds than those in the control (Figure 2(e)). If increasing root dry weight caused accelerated germination due to seed priming, the gradients of the correlation for priming might be similar to that of the control, suggesting that increased root dry weight was promoted by seed priming compared with that in the control with a decline in soil moisture content.

According to negative single curve between shoot dry weight and soil moisture, shoot dry weight was greatest at $9.5 \%, 10.3 \%$, and $7.5 \%$ soil moisture in the priming, control, and soaking seeds, respectively, and then shoot dry weight decreased with an increase or decrease in soil moisture content (Figure 2(d)). The T/R ratio decreased and root dry weight increased with a decline in soil moisture (Figures 2(e) and (f)). Therefore, decreasing shoot dry weight with a decline in soil moisture indicates adaptation to dry soil by increasing root distribution. At high soil moisture contents such as $15 \%$ and $20 \%$ in this study, germination time was longer in than other moisture levels (Figure 1), indicating that the period of shoot growth was shorter at higher soil moisture contents. Therefore, shoot dry weight decreased at high moisture levels.

Correlation between soil moisture content and the T/R ratio was distinctly different between the seeds obtained with priming and the other plots (Figure 2(f)). Growth of seedlings at the 2.4 leaf stage depends almost entirely on endosperm nutrients, although roots are capable of absorbing nutrients from the culture media from the time immediately after germination [43]. In this study, shoot length and dry weight of seedlings was measured $84 \mathrm{~h}$ after sowing; the nutrition of albumen may mainly be used for the growth of the seedling. Therefore, it is considered that the distribution of nutritional endosperm between the shoot and root is directly associated with the $\mathrm{T} / \mathrm{R}$ ratio. The results suggest that the seed detects the state of soil moisture content and the shoot and root nutrient distribution pattern in the seed changes, even in seedlings immediately after germination. At the first leaf stage, $70 \%$ endosperm is consumed under optimum cultivating conditions, and the dry weight of shoot and root increases [43]. At the growth patterns of seedlings under different moisture levels of media, the mesocotyl with coleoptile elongates until an approximate $\mathrm{pF}$ of 2.4; subsequently, coleoptile growth occurs preferentially as the $\mathrm{pF}$ decreases. When the culture media are saturated with water, the mesocotyl does not elongate, only the coleoptile grows [44]. Furthermore, roots appear to demonstrate decreased growth with decreasing $\mathrm{pF}$ [45]. Based on these observations and the report of Sato and Maruyama (2005), it is reasonable to say that the T/R ratio is a single negative curve, as shown in the control and soaking seeds (Figure 2(f)) [42]. However, the correlation between soil moisture content and the $\mathrm{T} / \mathrm{R}$ ratio in the priming seeds showed a positive linear regression (Figure 2(f)). These results suggest that seed priming promotes shoot growth with increasing soil moisture content and with decreasing soil moisture content promotes root growth. These observations are in close agreement with increasing dry weight of roots and shoots obtained with priming seeds with decreasing and increasing soil moisture content compared with that obtained with the control seeds (Figures 2(d) and (e)). These results suggest that rice seedlings obtained with priming seeds can avoid inhibited growth under dry and anaerobic soil conditions such as $3 \%$ and $20 \%$ soil moisture contents, although shoot growth is inferior compared with that in adequate soil moisture condition, e.g., $8 \%-11 \%$ soil moisture contents.

\section{Conclusion}

This study presents the effects of seed priming on germination and seedling vigor during emergence of rice under different soil moisture conditions. Emergence time was reduced in priming seeds compared with that in untreated seeds because of increased shoot elongation with dry matter production under a wide range of soil moisture conditions, except flood. Seedlings obtained with priming seeds showed increased growth compared with that obtained with untreated and soaking seeds because of the water absorption that occurred $12 \mathrm{~h}$ earlier. In conclusion, we determined the optimum soil moisture range for seed priming to be $8 \%-11 \%$ soil moisture content in this study.

\section{REFERENCES}

[1] A. G. Taylor, P. S. Allen, M. A. Bonnett, K. J. Bradford, J. S. Burris and M. K. Misra, "Seed Enhancements," Seed 
Science Research, Vol. 8, No. 2, 1998, pp. 245-256. doi:10.1017/S0960258500004141

[2] W. Heydecker, "Germination of an Idea: The Priming of Seeds," School of Agriculture Research, University of Nottingham, Nottingham, 1973, pp. 50-67.

[3] S. H. Gurusinghe, Z. Y. Cheng and K. J. Bradford, "Cell Cycle Activity during Seed Priming Is Not Essential for Germination Advancement in Tomato," Journal of Experimental Botany, Vol. 50, No. 330, 1990, pp. 101-106. doi:10.1093/jxb/50.330.101

[4] K. Gallardo, C. Job, S. P. C. Groot, M. Puype, H. Demol, J. Vandekerckhove and D. Job, "Proteomic Analysis of Arabidopsis Seed Germination and Priming," Plant physiology, Vol. 126, No. 2, 2001, pp. 835-848. doi:10.1104/pp.126.2.835

[5] J. K. Bradford, "Manipulation of Seed Water Relations via Osmotic Priming to Improve Germination under Stress Conditions," Hortscience, Vol. 21, 1986, pp. 11051112.

[6] C. A. Parera and D. J. Cantliffe, "Presowing Seed Priming," Horticultural Reviews, Vol. 16, 1994, pp. 109142.

[7] R. B. Austin, P. C. Longden and J. Hutchinson, "Some Effects of 'Hardening' Carrot Seed," Annual Botany, Vol. 33, 1969, pp. 883-895.

[8] L. Enu-Kwesi, M. Nwalozie and D. I. Anyanwu, "Effect of Pre-Sowing 'Hydration-Dehydration' on Germination, Vegetative Growth and Fruit Yield of Abelmoschus esculentus Growth under Two Soil Moisture Regimes," Tropical Agriculture (Trinidad), Vol. 63, No. 3, 1986, pp. 181-184.

[9] M. A. Bennett and L. Waters Jr., "Germination and Emergence of High-Sugar Sweet Corn in Improved by Presowing Hydration of Seed," Hortscience, Vol. 22, No. 2, 1987, pp. 236-238.

[10] R. Dolly and S. Nakamura, "The Effect of HydrationDehydration Pretreatments on Eggplant and Radish Seed Viability and Vigor," Seed Science and Technology, Vol. 16, 1988, pp. 123-130.

[11] H. Ando and T. Kobata, "Effect of Seed Hardening, Wetting and Redrying before Sowing, on Germination and Seedling Emergence of a Japanese Wheat Variety Norin 61 in Desiccated Soil," Plant Production Science, Vol. 4, 2001, pp. 50-55. doi:10.1626/pps.4.50

[12] M. Yamamoto, "Effects of Temporary Water Stress in Germinating Seeds on Germination in Weed Seeds," Bulletin of Yamagata University, Natural Science, Vol. 11, 1986, pp. 317-326 (in Japanese).

[13] R. H. Ellis and P. D. Butcher, "The Effects of Priming and 'Natural' Differences in Quality amongst Onion Seed Lots on the Response of the Rate of Germination to Temperature and the Identification of the Characteristics under Genotypic Control," Journal of Experimental Botany, Vol. 39, No. 204, 1988, pp. 935-950. doi: $10.1093 / \mathrm{j} \times \mathrm{b} / 39.7 .935$

[14] G. H. Zheng, W. W. Ronald, S. E. Alfred and G. V. Lawrence, "Enhancement of Canola Seed Germination and
Seedling Emergence at Low Temperature by Priming," Crop Science, Vol. 34, No. 6, 1994, pp. 1589-1593. doi:10.2135/cropsci1994.0011183X003400060031x

[15] T. A. Evans and W. G. Pill, "Emergence and Seedling Growth from Osmotically Primed or Pregerminated Seeds of Asparagus (Asparagus officinalis L.)," Journal of Horticulutural Science, Vol. 64, No. 3, 1989, pp. 275-282.

[16] A. B. Ayers and H. E. Hayward, "A Method for Measuring the Effects of Soil Salinity on Seed Germination with Observations on Several Crop Plants," Proceeding of Soil Science Society of American, USA, Vol. 13, 1948, pp. 224-226.

[17] I. Afzal, A. M. A. Basra, N. Ahmad and T. E. Lodhi, "Counteraction of Salinity Stress on Wheat Plants by PreSowing Seed Treatments," Pakistan Journal of Agricultural Science, Vol. 44, No. 1, 2007, pp. 50-58.

[18] M. Ashraf and M. R. Foolad, "Pre-Sowing Seed Treatment: A Shotgun Approach to Improve Germination, Plant Growth, and Crop Yield under Saline and NonSaline Conditions," Advances in Agronomy, Vol. 88, 2005, pp. 223-271. doi:10.1016/S0065-2113(05)88006-X

[19] N. Yamada, H. Suge and H. Nakamura, "Chemical Control of Plant Growth and Development (1) Germination of Rice Seed as Affected by Sprouting and Gibberellin Application," Japanese Journal of Crop Science, Vol. 31, 1962, pp. 253-257. doi:10.1626/jcs.31.253

[20] M. Farooq, S. M. A. Basra, I. Afzal and A. Khaliq, "Optimization of Hydropriming Techniques for Rice Seed Invigoration," Seed Science \& Technology, Vol. 34, No. 2, 2006, pp. 507-512.

[21] S. S. Lee and J. H. Kim, "Morphological Change, Sugar Content and $\alpha$-Amylase Activity of Rice Seeds under Various Priming Conditions," Korean Journal of Crop Science, Vol. 44, No. 2, 1999, pp. 138-142.

[22] M. Farooq, S. M. A. Basra, M. Khalid, R. Tabassum and T. Mahmood, "Nutrient Homeostasis, Metabolism of Reserves, and Seedling Vigor as Affected by Seed Priming in Coarse Rice," Canadian Journal of Botany, Vol. 84, No. 8, 2006, pp. 1196-1202. doi:10.1139/b06-088

[23] M. Farooq, S. M. A. Basra, R. Tabassum and I. Afzal, "Enhanceing the Performance of Direct Seeded Fine Rice by Seed Priming," Plant Production Science, Vol. 9, No. 4, 2006, pp. 446-456. doi:10.1626/pps.9.446

[24] H. Shiratsuchi, H. Kitagawa, K. Okada, K. Nakanishi, M. Suzuki, A. Ogura, M. Matsuzaki and S. Yasumoto, "Development of Rice 'Seed-Mats' Consisting of Hardened Seeds with a Cover of Soil for the Rice Transplanter," Plant Production Science, Vol. 11, No. 1, 2008, pp. 108115. doi: $10.1626 / \mathrm{pps} .11 .108$

[25] M. Farooq, S. M. A. Basra, A. Aahid and N. Ahmad, "Changes in Nutrient-Homeostasis and Reserves Metabolism during Rice Seed Priming: Consequences for Seedling Emergence and Growth," Agricultural Science in China, Vol. 9, No. 2, 2010, pp. 191-198. doi:10.1016/S1671-2927(09)60083-3

[26] M. Farooq, S. M. A. Basra, H. A. Karim and I. Afzal, "Optimization of Seed Hardening Techniques for Rice 
Seed Invigoration," Emirates Journal of Agricultural Science, Vol. 16, 2004, pp. 48-57.

[27] S. M. A. Basra, M. Farooq, R. Tabassum and N. Ahmad, "Physiological and Biochemical Aspects of Pre-Sowing Seed Treatments in Fine Rice (Oryza sativa L.)," Seed Science \& Technology, Vol. 33, No. 3, 2005, pp. 623-628.

[28] H. Ando and T. Kobata, "Does Wetting and Redrying the Seed before Sowing Improve Rice Germination and Emergence under Low Soil Moisture Condition?" Plant Production Science, Vol. 3, No. 2, 2000, pp. 161-163. doi:10.1626/pps.3.161

[29] S. S. Lee, J. H. Kim, S. B. Hong, S. H. Yun and E. H. Park, "Priming Effect of Rice Seeds on Seedling Establishment under Adverse Soil Condition," Korean Journal of Crop Science, Vol. 43, No. 3, 1998, pp. 194-198.

[30] H. Shiratsuchi, S. Morita and J. Takanashi, "Differences in the Rate of Seedling Emergence among Rice Cultivars under Low Soil-Moisture Conditions," Plant Production Science, Vol. 4, No. 2, 2001, pp. 94-102. doi:10.1626/pps.4.94

[31] K. Kawaguchi, "Soil Water and Soil Air," In: K. Kawaguchi, K. Kumada, S. Aomine, S. Kosaka, H. Okajima, S. Sasaki, Y. Takai, I. Yamane and S. Hunahiki, Eds., Soil Science, Asakurasyotenn Press, Tokyo, 1974, pp. 82-97 (in Japanese).

[32] H. Ando and T. Kobata, "Effect of Seed Hardening on the Seedling Emergence and $\alpha$-Amylase Activity in the Grains of Wheat and Rice Sown in Dry Soil," Japanese Journal of Crop Science, Vol. 71, No. 2, 2002, pp. 220-225 (in Japanese). doi:10.1626/jcs.71.220

[33] S. S. Lee and J. H. Kim, "Total Sugars, $\alpha$-Amylase Activity, and Germination after Priming of Normal and Aged Rice Seeds," Korean Journal of Crop Science, Vol. 45, No. 2, 2000, pp. 108-111.

[34] D. L. Taylor, "Influence of Oxygen Tension on Respiration, Fermentation, and Growth in Wheat and Rice," American Journal of Botany, Vol. 29, No. 9, 1942, pp. 721-738. doi: $10.2307 / 2437726$

[35] A. Alpi and H. Beevers, "Effect of $\mathrm{O}_{2}$ Concentration on Rice Seedlings," Plant Physiology, Vol. 71, No. 1, 1983, pp. 30-34. doi:10.1104/pp.71.1.30

[36] M. Yamauchi, A. M. Aguilar, D. A. Vaughan and D. V. Seshu, "Rice (Oryza sativa L.) Germplasm Suitable for
Direct Sowing under Flooded Soil Surface," Euphytica, Vol. 67, No. 3, 1993, pp. 177-184. doi:10.1007/BF00040619

[37] M. Yamauchi and T. Winn, "Rice Seed Vigor and Seedling Establishment in Anaerobic Soil," Crop Science, Vol. 36, No. 3, 1996, pp. 680-686. doi:10.2135/cropsci1996.0011183X003600030027x

[38] S. E. El-Hendawy, C. Sone, O. Ito and J. I. Sakagami, "Evaluation of Germination Ability in Rice Seeds under Anaerobic Conditions by Cluster Analysis," Research Journal of Seed Science, Vol. 4, No. 2, 2011, pp. 82-93. doi:10.3923/rjss.2011.82.93

[39] P. Perata, J. P-Romero, T. Akazawa and J. Yamaguchi, "Effect of Anoxia on Starch Breakdown in Rice and Wheat Seeds," Planta, Vol. 188, No. 4, 1992, pp. 611618. doi:10.1007/BF00197056

[40] A. M. Ismail, E. S. Ella, G. V. Vergara and D. J. Mackill, "Mechanisms Associated with Tolerance to Flooding during Germination and Early Seedling Growth in Rice (Oryza sativa L.)," Annals of Botany, Vol. 103, No. 2, 2009, pp. 197-209. doi:10.1093/aob/men211

[41] T. Sato and S. Maruyama, "Seedling Emergence and Establishment under Drained Conditions in Rice DirectSown into Puddled and Leveled Soil-Effect of Calcium Peroxide Seed Coating and Sowing Depth," Plant Production Science, Vol. 5, 2002, pp. 71-76. doi:10.1626/pps.5.71

[42] T. Sato and S. Maruyama, "Seedling Growth and DryMatter Production under Drained Conditions in Rice Direct-Sown into Puddled and Leveled Soil," Plant Production Science, Vol. 8, 2005, pp. 209-215. doi:10.1626/pps.8.209

[43] K. Hoshikawa, "The Growing Rice Plant-An Anatomical Monograph," Nobunkyo Press, Tokyo, 1989, pp. 30-31, 59-67.

[44] N. Takahashi, "Adaptive Importance of Mesocotyl and Coleoptile Growth in Rice under Different Moisture Regime," Australian Journal of Plant Physiology, Vol. 5, No. 4, 1978, pp. 511-517. doi:10.1071/PP9780511

[45] N. Takahashi, "Physiology of Seed Germination," In: T. Matsuo, K. Kumazawa, R. Ishii and H. Hirata, Eds., Science of Rice Plant Vol. 2 Physiology. I. Physiology of Development, Nobunkyo Press, Tokyo, 1995, pp. 35-65. 